Abstracta Iranica Abstracta Iranica

Revue bibliographique pour le domaine irano-aryen

Volume 37-38-39 | 2018

Comptes rendus des publications de 2014-2016

\title{
Dan P. Cole. Lahav V. The Iron, Persian, and Hellenistic Occupations within the Walls at Tell Halif. Excavations in Field II, 1977-1980
}

\section{Astrid Nunn}

\section{(2) OpenEdition \\ Journals}

Édition électronique

URL : http://journals.openedition.org/abstractairanica/44234

DOI : 10.4000/abstractairanica.44234

ISBN : 1961-960X

ISSN : 1961-960X

Éditeur :

CNRS (UMR 7528 Mondes iraniens et indiens), Éditions de l'IFRI

\section{Référence électronique}

Astrid Nunn, « Dan P. Cole. Lahav V. The Iron, Persian, and Hellenistic Occupations within the Walls at Tell Halif. Excavations in Field II, 1977-1980 », Abstracta Iranica [En ligne], Volume 37-38-39 | 2018, document 34, mis en ligne le 30 décembre 2018, consulté le 02 octobre 2020. URL : http://

journals.openedition.org/abstractairanica/44234 ; DOI : https://doi.org/10.4000/abstractairanica 44234

Ce document a été généré automatiquement le 2 octobre 2020.

Tous droits réservés 


\title{
Dan P. Cole. Lahav V. The Iron, Persian, and Hellenistic Occupations within the Walls at Tell Halif. Excavations in Field II, 1977-1980
}

\author{
Astrid Nunn
}

\section{RÉFÉRENCE}

Dan P. Cole. Lahav V. The Iron, Persian, and Hellenistic Occupations within the Walls at Tell Halif. Excavations in Field II, 1977-1980. [Reports of the Lahav Research Project.

Excavations at Tell Halif, Israel, vol. V], Eisenbrauns, 2015, 267 p.

1 Le site du Tell Halif (ou Tell Khuweilifeh) est situé près du kibbutz Lahav à $14 \mathrm{~km}$ au nord-est de Beersheba dans l'ancienne province d'Idumée. Sa phase la plus ancienne remonte à environ 3500 av. J.-C. Rien n'est remarquable dans les vestiges d'époque achéménide des $V^{\text {ème }}$ et IV ème s. av. n. è. (Phase/Stratum 5). Mais la découverte de nombreux cavaliers en terre cuite de cette époque (voir ci-dessous) sort assez de l'ordinaire pour que ce site soit recensé ici.

Ce site reste pendant la période achéménide ce qu'il était déjà avant: une petite bourgade entourée d'un mur (p. 37-44). L'architecture domestique de cette époque s'apparente plutôt au modèle assyrien à cour qu'au type palestinien à 3 ou 4 pièces. 


\section{AUTEURS}

\section{ASTRID NUNN}

Université de Munich 